Article

\title{
Trace Element Uptake by Herbaceous Plants from the Soils at a Multiple Trace Element-Contaminated Site
}

\author{
Obinna Elijah Nworie ${ }^{1}$, Junhao Qin ${ }^{1,2}$ and Chuxia Lin ${ }^{1, *}$ \\ 1 School of Environment and Life Science, University of Salford, Greater Manchester M5 4WT, UK; \\ O.Nworie@edu.salford.ac.uk (O.E.N.); qinjunhao2015@gmail.com (J.Q.) \\ 2 Key Laboratory of Agro-Environment in the Tropics, Ministry of Agriculture, South China Agricultural \\ University, Guangzhou 510642, China \\ * Correspondence: C.Lin@salford.ac.uk; Tel.: +44-161-295-5356
}

Received: 3 December 2018; Accepted: 15 January 2019; Published: 17 January 2019

check for updates

\begin{abstract}
The uptake of trace elements by wild herbaceous plants in a multiple trace elementcontaminated site was investigated. The bioaccumulation factor (BF) of trace elements was markedly variable among the different plant species. On average, the $\mathrm{BF}$ for various trace elements was in the following decreasing order: $\mathrm{Zn}>\mathrm{Cu}>\mathrm{Mn}>\mathrm{Ni}>\mathrm{As}>\mathrm{Pb}>\mathrm{Cr}$. The translocation factor among the investigated plant species was also considerably variable and showed the following decreasing order: $\mathrm{Mn}>\mathrm{Zn}>\mathrm{Ni}>\mathrm{Cu}>\mathrm{Cr}>\mathrm{As}>\mathrm{Pb}$. Several hyperaccumulating plants were identified: Artemisia vulgaris for As, Mn and Zn, Phalaris arundinacea for $\mathrm{Mn}$ and Ni, Heracleum sphondylium for $\mathrm{Cr}$ and $\mathrm{Zn}$, and Bistorta officinalis for Mn and $\mathrm{Zn}$. The marked accumulation of trace elements in the plant tissue suggests that the site may not be suitable for urban agricultural production. The plant tissue-borne trace elements could affect microbial activities and consequently interfere with the ecosystem functioning in the affected areas.
\end{abstract}

Keywords: plant uptake; trace element; contaminated site; environmental risk; soil

\section{Introduction}

Soil-plant translocation of trace elements is a key step leading to entry of these potentially toxic substances into the food chain [1]. Uptake of toxic elements by plants growing in contaminated soils represents a potential risk for both humans and animals due to accumulation of these trace elements in food chain [2,3]. In contaminated lands, excessive amounts of trace elements may be taken and accumulated in the above-ground portion of plants, which could lead to entry of trace elements into the food chain [4]. Trace elements which are available for plant uptake are those that exist mostly in soluble forms in soil solutions [5]. Empirical models that are effective for field applications, and that take into account plant characteristics and soil factors, have been successfully used to predict concentrations of heavy metals in plants [6]. A study by Adams et al. [7] predicted the concentrations of Cd in wheat grain based on the relationship between $\mathrm{Cd}$ concentration in wheat grain and soil $\mathrm{pH}$. Similarly, Cao et al. [8] successfully predicted heavy metal concentrations in rice grain using a combination of soil $\mathrm{pH}$ and EDTA-extractable $\mathrm{Cd}, \mathrm{Zn}, \mathrm{Cr}, \mathrm{Pb}$ and $\mathrm{Cu}$ concentrations in the soils. Warne et al. [9] also found that the use of soil properties to estimate phytotoxic effects of heavy metals across different soil-crop systems was one of the fundamental steps in improving risk assessment of heavy metals in soil.

Plant uptake of trace elements could pose a risk to wild animals, grazing cattle and humans who are exposed to the contaminated plants [10]. To assess the environmental risk from the exposure to contaminated plant tissues in a contaminated site, it is necessary to understand the status of trace elements in soil-plant systems. Although there has been some work on trace element uptake 
by plants in contaminated soils, previous studies have focused on the phytoextracting capacity of hyperaccumulating plants in greenhouse settings. There have been only a few studies being conducted under field conditions. For example, Nguyen et al. [11] reported that Eleocharis acicularis hyper-accumulated a significant amount of $\mathrm{Pb}$ in an abandoned mine site. Similarly, Ranjeev et al. [12] found that Eichhornnia crassipes accumulated considerable amounts of $\mathrm{Fe}, \mathrm{Mn}$ and $\mathrm{Cu}$ in a site contaminated with industrial effluents. Furthermore, Yoon et al. [4] found that various herbaceous plants investigated in a contaminated site in Florida had the capacity to accumulate $\mathrm{Pb}, \mathrm{Cu}$ and $\mathrm{Zn}$.

Although there has been some work done on trace element uptake by plants in contaminated soils, there is still a paucity of information on the uptake and translocation of trace elements by herbaceous plants in multi-contaminated lands. This study aims to evaluate the uptake of various trace elements by a range of herbaceous plants and the associated environmental risk in a historical landfill site with industrial wastes being disposed of during the Industrial Revolution. It was intended to be a preliminary baseline study to provide information for selection of the long-term monitoring sites and conduct of greenhouse experiments to explore the insights into the mechanisms responsible for the plant uptake of the investigated trace elements.

\section{Materials and Methods}

\subsection{The Study Site}

The study site is part of the Moston Brook area that is situated in the Greater Manchester region, England (latitude: $53.515889^{\circ} \mathrm{N}$; longitude: $002.155625^{\circ} \mathrm{W}$ ) (Figure 1).

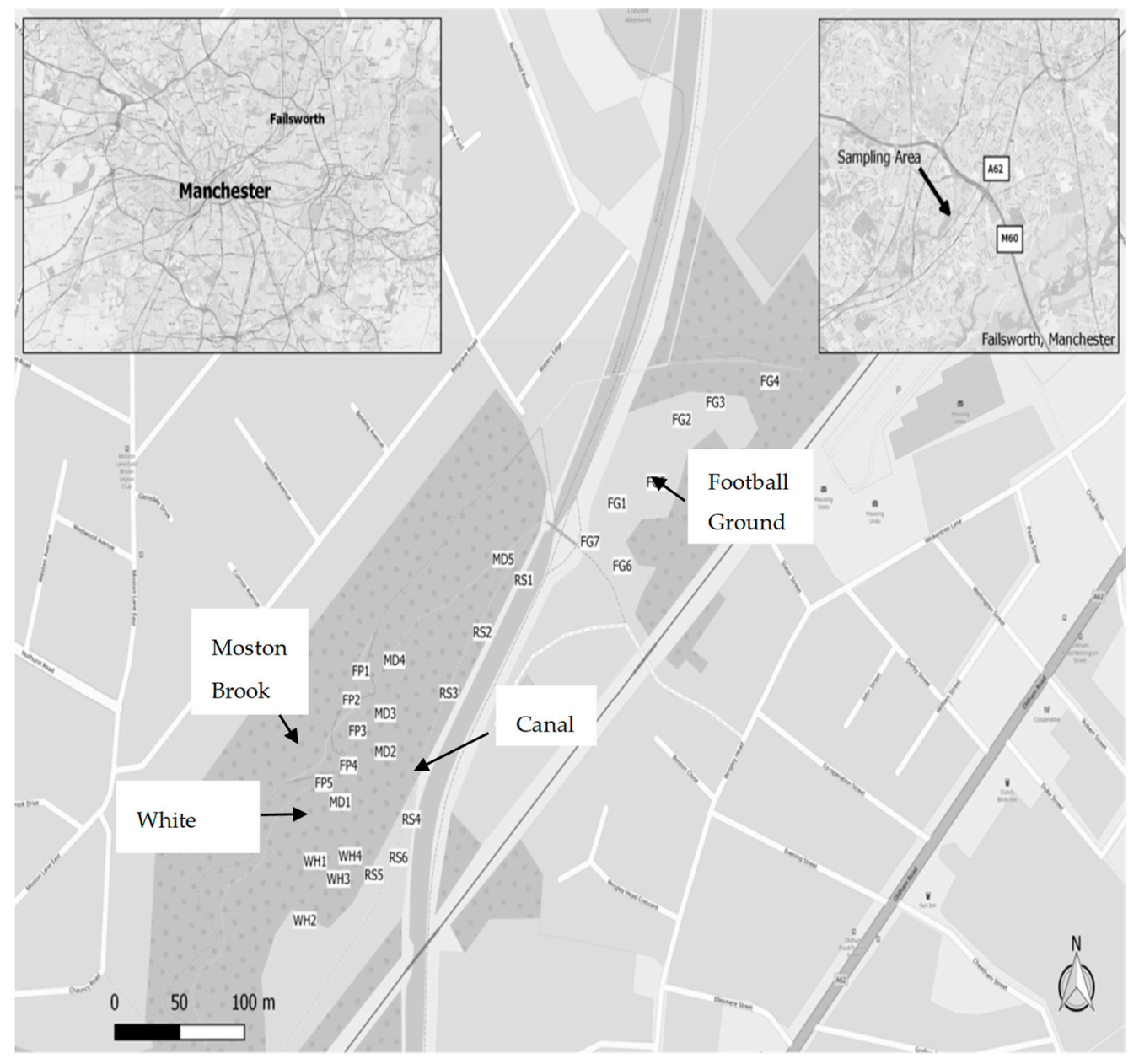

Figure 1. Map showing the study area and sampling locations. 
During the period of Industrial Revolution, the Moston Brook area was part of the "cottonopolis" with dyeing and bleaching of finished cotton fabrics, and printing and brick making being the major industrial activities in the area [13]. The investigated area is part of a closed landfill site that received various solid industrial wastes in the past. Since the disposal of wastes took place prior to the enactment of the Pollution Control Act in 1974, it is practically impossible to track down the history of landfill operations. However, an area of contamination (locally known as "White Hills") has been identified between the canal and the brook with the soils consisting of pale-yellow materials. Contamination is suspected to extend in a north-south direction and there is a concern that runoff and erosion from the exposed bank is impacting the water and sediment quality of the brook. Another area of contamination (locally known as "Football Ground") that is largely unvegetated has also been identified, which is located on the opposite side of the canal from the "White Hills" [13]. The site is currently being used as a public open space for the local people and visitors and the local authorities have proposed to re-develop the site for recreation and other beneficial uses [13].

\subsection{Field and Laboratory Methods}

Twenty-seven herbaceous plants (representing 26 dominant species) with their corresponding soils were collected across the study area in May 2015. The sampling locations are shown in Figure 1. Samples WH1-4 were collected from the central part of the "White Hills"; Samples MD1-5 were collected from the area extending north from the central part of the "White Hills"; Samples FP1-5 were collected from the floodplain of the Moston Brook; Samples RS1-6 were collected from the soils along the road running parallel to the canal; and Samples FG1-7 were collected from the "Football Ground". At each location, the plant with its corresponding rhizospheric soil was taken using a spade. The samples were then put in appropriately labelled polyethylene bags and immediately transported to the laboratory on the same day for pretreatment.

In the laboratory, the plants were carefully separated from the soils. The soil samples were then oven-dried at $40{ }^{\circ} \mathrm{C}$, ground to pass a $2 \mathrm{~mm}$ sieve and stored in sealable laboratory bags prior to analysis. The plant samples were washed with deionized water to remove all the soils attached to the roots, dried with a paper towel and air-dried for about two hours. The air-dried plant samples were then separated into roots and shoots and the fresh biomass of both root and shoot portions were measured. The fresh plant parts were contained in paper bags and oven-dried at $65^{\circ} \mathrm{C}$ for three days. After oven-drying, the dry biomass of root and shoot portions was determined. Each of the dried plant samples was then ground using an electrical plant tissue pulverizer and stored in a sealable bag prior to analysis.

Soil $\mathrm{pH}$ and electrical conductivity (EC) were measured in 1:5, soil:water extracts using a calibrated $\mathrm{pH}$ meter and EC meter, respectively. The concentration of trace elements contained in the soils was determined by X-ray fluorescence microscopy (Niton XL2 Gold Handheld XRF Analyser, Winchester, UK). The analytical procedure is as follows: a sub-sample was further ground to pass a $0.063 \mathrm{~mm}$ sieve; the samples were agitated for $5 \mathrm{~min}$ by mechanical sieve shaker and then $5 \mathrm{~g}$ of each of the soil samples was transferred into an XRF sampling cup; a thin cling film sheet was used to cover the base of the cup prior to XRF analysis. During XRF analysis, the XRF analyser was placed on holding support and then connected to a laptop through which real time data of the analysis was obtained in an excel file. The instrument was calibrated by analysing the 73,308 standard reference materials prior to proper analysis. To ensure accuracy and reliability of the results obtained, all analyses were performed in duplicates and the analysis time was $240 \mathrm{~s}$.

The concentration of trace elements in the plant tissues was determined by ICP-OES (Varian 720ES ICP-OES, Palo Alto, CA, USA). For each plant tissue sample, $0.5 \mathrm{~g}$ of the powdered sample was weighed and added into a microwave digestion tube, followed by adding $1 \mathrm{~mL}$ of $30 \%(\mathrm{~m} / \mathrm{m}) \mathrm{H}_{2} \mathrm{O}_{2}$ and $7 \mathrm{~mL}$ of concentrated $\mathrm{HNO}_{3}$ solution. The tubes were fitted with bungers and closed appropriately with lids to prevent loss of volatile elements during digestion and placed into microwave carousel. The microwave digestion was done by firstly increasing the temperature linearly from 25 to $90{ }^{\circ} \mathrm{C}$ for 4 
min; secondly, the temperature was maintained steadily at $90{ }^{\circ} \mathrm{C}$ for $2 \mathrm{~min}$; thirdly, the temperature was increased linearly to $180{ }^{\circ} \mathrm{C}$ for over $6 \mathrm{~min}$; and finally, the temperature was maintained at $180^{\circ} \mathrm{C}$ for $10 \mathrm{~min}$ [14]. After cooling, the digested plant samples were filtered using Whatman filter papers (No. 42). The filtrates were then diluted to a final volume of $25 \mathrm{~mL}$ with deionized water. The diluted samples were stored at $4{ }^{\circ} \mathrm{C}$ in a refrigerator prior to analysis of trace elements using ICP-OES.

\section{Results}

\section{1. $p H$ and $E C$}

The $\mathrm{pH}$ and EC of the investigated soils are presented in Table 1. $\mathrm{pH}$ ranged from 5.46 to 8.32 with a median value of 6.50 . The median of EC was $64.5 \mu \mathrm{S} / \mathrm{cm}$ with a range of $17.6-182$. No clear spatial variation trend is observed though the $\mathrm{pH}$, and $\mathrm{EC}$ tended to be lower in the WH portion (WH1-4) and tended to be higher in the FP portion, as compared to other portions. There is no close relationship $\left(R^{2}\right.$ $=0.26, n=27$ ) between the $\mathrm{pH}$ and $\mathrm{EC}$.

Table 1. $\mathrm{pH}$ and Electrical Conductivity of the investigated soils.

\begin{tabular}{|c|c|c|}
\hline Location & $\mathrm{pH}$ & $\mathrm{EC}(\mu \mathrm{S} / \mathrm{cm})$ \\
\hline FG1 & 7.12 & 39.1 \\
\hline FG2 & 6.62 & 35.2 \\
\hline FG3 & 5.86 & 70.6 \\
\hline FG4 & 8.32 & 96.4 \\
\hline FG5 & 6.57 & 17.6 \\
\hline FG6 & 6.16 & 64.8 \\
\hline FG7 & 6.76 & 182 \\
\hline FP1 & 7.58 & 39.2 \\
\hline FP2 & 7.69 & 135 \\
\hline FP3 & 6.27 & 70.6 \\
\hline FP4 & 7.41 & 138 \\
\hline FP5 & 7.10 & 152 \\
\hline MD1 & 7.53 & 123 \\
\hline MD2 & 5.46 & 38.9 \\
\hline MD3 & 6.21 & 42.1 \\
\hline MD4 & 7.61 & 153 \\
\hline MD5 & 7.02 & 64.3 \\
\hline RS1 & 6.39 & 116 \\
\hline RS2 & 6.47 & 72.4 \\
\hline RS3 & 6.50 & 45.2 \\
\hline RS4 & 6.81 & 132 \\
\hline RS5 & 5.50 & 53.5 \\
\hline RS6 & 6.25 & 61.5 \\
\hline WH1 & 5.85 & 37.5 \\
\hline WH2 & 6.12 & 62.1 \\
\hline WH3 & 6.16 & 51.4 \\
\hline WH4 & 6.09 & 45.5 \\
\hline Median & 6.50 & 64.5 \\
\hline Range & $5.46-8.32$ & $17.6-182$ \\
\hline
\end{tabular}

\subsection{Total Concentration of Trace Elements in the Investigated Soils}

Various trace elements in the investigated soils were spatially variable. In terms of median concentration, they were in the following decreasing order: $\mathrm{Mn}>\mathrm{Pb}>\mathrm{As}>\mathrm{Cr}>\mathrm{Zn}>\mathrm{Cu}>\mathrm{Ni}$. There were a few spots with concurrent presence of $\mathrm{Cu}, \mathrm{Mn}, \mathrm{Ni}, \mathrm{Pb}$ and $\mathrm{Zn}$ at very high concentration (FG1, FG2, FG5 and RS3). Most of the soils had a concentration of $\mathrm{Cr}$ over $100 \mathrm{mg} / \mathrm{kg}$. There were seven spots where the concentration of As was greater than $500 \mathrm{mg} / \mathrm{kg}$ (Table 2). 
Table 2. Total concentration (mg element/kg dry weight) of trace elements in the investigated soils.

\begin{tabular}{|c|c|c|c|c|c|c|c|}
\hline Location & As & $\mathrm{Cr}$ & $\mathrm{Cu}$ & Mn & $\mathrm{Ni}$ & $\mathrm{Pb}$ & $\mathrm{Zn}$ \\
\hline FG1 & 69 & 155 & 2768 & 3855 & 802 & 1492 & 1263 \\
\hline FG2 & 80 & 154 & 3348 & 3458 & 920 & 1587 & 1026 \\
\hline FG3 & 770 & 223 & 59 & 361 & $\mathrm{UDL}^{\mathrm{a}}$ & 649 & 89 \\
\hline FG4 & 12 & 47 & 197 & 397 & 55 & 114 & 186 \\
\hline FG5 & 39 & 121 & 1237 & 3499 & 1075 & 891 & 1881 \\
\hline FG6 & 40 & 103 & 408 & 767 & 145 & 345 & 218 \\
\hline FG7 & 51 & 133 & 626 & 1017 & 129 & 402 & 580 \\
\hline FP1 & 510 & 161 & 78 & 502 & 57 & 362 & 143 \\
\hline FP2 & 148 & 144 & 170 & 774 & 71 & 434 & 453 \\
\hline FP3 & 472 & 136 & 119 & 499 & 17 & 919 & 242 \\
\hline FP4 & 54 & 108 & 63 & 428 & 53 & 137 & 128 \\
\hline FP5 & 50 & 95 & 60 & 416 & 55 & 132 & 119 \\
\hline MD1 & 34 & 87 & 32 & 581 & 11 & 46 & 72 \\
\hline MD2 & 1132 & 126 & 38 & 49 & UDL & 623 & 28 \\
\hline MD3 & 269 & 142 & 35 & 340 & 6 & 191 & 71 \\
\hline MD4 & 761 & 204 & 79 & 309 & UDL & 690 & 89 \\
\hline MD5 & 215 & 126 & 57 & 432 & 11 & 253 & 121 \\
\hline RS1 & 350 & 165 & 78 & 351 & 24 & 337 & 174 \\
\hline RS2 & 451 & 172 & 52 & 362 & 22 & 330 & 95 \\
\hline RS3 & 88 & 177 & 2380 & 1957 & 425 & 1316 & 1450 \\
\hline RS4 & 324 & 152 & 75 & 524 & 9 & 329 & 118 \\
\hline RS5 & 857 & 202 & 89 & 2245 & UDL & 597 & 92 \\
\hline RS6 & 688 & 217 & 88 & 254 & UDL & 569 & 109 \\
\hline WH1 & 993 & 200 & 61 & 383 & UDL & 1380 & 89 \\
\hline WH2 & 96 & 108 & 134 & 312 & 10 & 156 & 95 \\
\hline WH3 & 268 & 139 & 51 & 466 & UDL & 257 & 107 \\
\hline WH4 & 125 & 117 & 54 & 394 & 17 & 148 & 98 \\
\hline Median & 215 & 142 & 78 & 432 & 17 & 362 & 119 \\
\hline Min & 12 & 47 & 32 & 49 & UDL & 46 & 28 \\
\hline Max & 1132 & 223 & 3348 & 3855 & 1075 & 1587 & 1881 \\
\hline UK soil range ${ }^{b}$ & $0.5-143$ & $1.14-236$ & $2.27-96.7$ & $10-12,200$ & $1.16-216$ & $2.6-713$ & $2.63-442$ \\
\hline UK soil median $\mathrm{b}$ & 7.1 & 29.2 & 17.2 & 420 & 15.8 & 37.4 & 65.9 \\
\hline UK screening level ${ }^{\mathrm{c}}$ & $32-40^{d}$ & - & - & - & - & $82-330^{\mathrm{d}}$ & - \\
\hline
\end{tabular}

\subsection{Concentration of Trace Elements in Plant Tissues}

\subsubsection{Roots}

The concentration of trace elements in the roots of the investigated plant species is given in Table 3. For the investigated plant species, the concentration of trace elements in the root portion varied markedly from plant species to plant species. The median concentration of root-borne trace elements was in the following decreasing order: $\mathrm{Mn}>\mathrm{Zn}>\mathrm{Cu}>\mathrm{Pb}>\mathrm{Ni}>\mathrm{As}>\mathrm{Cr}$.

Root-borne As had a median concentration of $5 \mathrm{mg} / \mathrm{kg}$ with a range of 1-103 $\mathrm{mg} / \mathrm{kg}$. Among the investigated plant species, Bistorta officinalis and Lolium pratense had the first and second highest concentration of As in the root portion. Dactylis glomerata and Urtica dioica also had relatively higher concentration of root-borne As, as compared to most of the investigated plant species. In contrast, some plant species such as Artemisia vulgaris, Chamerion angustifolium and Plantago lanceolata showed very low concentration of root-borne As $(<2 \mathrm{mg} / \mathrm{kg})$. The root-borne $\mathrm{Cr}$ ranged from under detection limit to $46 \mathrm{mg} / \mathrm{kg}$ with a median concentration of $3 \mathrm{mg} / \mathrm{kg}$. Dactylis glomerata had the highest concentration of $\mathrm{Cr}$ in the root portion while Galium aparine had no detectable $\mathrm{Cr}$ in the plant roots. Heracleum sphondylium, Impatiens glandulifera, Holcus lanatus also showed very low root-borne $\mathrm{Cr}$ concentration $(<1 \mathrm{mg} / \mathrm{kg})$. The root-borne $\mathrm{Cu}$ ranged from $9 \mathrm{mg} / \mathrm{kg}$ to $731 \mathrm{mg} / \mathrm{kg}$ with a median concentration of $42 \mathrm{mg} / \mathrm{kg}$. Agrostis tenuis had the highest concentration $(731 \mathrm{mg} / \mathrm{kg})$ of root-borne 
$\mathrm{Cu}$ while Heracleum sphondylium had the lowest concentration of $\mathrm{Cu}(9 \mathrm{mg} / \mathrm{kg})$. The concentration of root-borne Mn ranged from 25 to $584 \mathrm{mg} / \mathrm{kg}$ with a median concentration of $182 \mathrm{mg} / \mathrm{kg}$. Phleum pratense had the highest concentration of root-borne $\mathrm{Mn}$ among the investigated plant species. The lowest concentration of root-borne Mn was observed in Heracleum sphondylium with a concentration of $25 \mathrm{mg} / \mathrm{kg}$. The root-borne Ni ranged from 1 to $317 \mathrm{mg} / \mathrm{kg}$ among all the investigated plant species. The median root-borne $\mathrm{Ni}$ was $33 \mathrm{mg} / \mathrm{kg}$. The highest root-borne $\mathrm{Ni}$ concentration $(317 \mathrm{~m} / \mathrm{kg})$ was found in Agrostis tenuis, followed by Agrostis stolonifera. The lowest root-borne Ni concentration was recorded in Galium aparine. The concentration of root-borne $\mathrm{Pb}$ ranged from 3 to $256 \mathrm{mg} / \mathrm{kg}$ among the investigated plant species. The median concentration of root-borne $\mathrm{Pb}$ was $23 \mathrm{mg} / \mathrm{kg}$. Agrostis tenuis had the highest concentration of root-borne $\mathrm{Pb}$, followed by Agrostis stolonifera. The lowest concentration of root-borne $\mathrm{Pb}$ was observed in Chamerion angustifolium. The root-borne $\mathrm{Zn}$ had a median concentration of $122 \mathrm{mg} / \mathrm{kg}$ with a range of $50-558 \mathrm{mg} / \mathrm{kg}$. Agrostis tenuis had the highest concentration of root-borne $\mathrm{Zn}$ while the lowest concentration was held by Chamerion angustifolium.

Table 3. Concentration (mg element/kg dry weight) of trace elements in the roots of the investigated plant species.

\begin{tabular}{|c|c|c|c|c|c|c|c|c|c|}
\hline Location & Plant Species & Common Name & As & $\mathrm{Cr}$ & $\mathrm{Cu}$ & Mn & $\mathrm{Ni}$ & $\mathrm{Pb}$ & $\mathrm{Zn}$ \\
\hline FG1 & Agrostis stolonifera & Creeping bent & 5 & 12 & 422 & 478 & 191 & 182 & 333 \\
\hline FG2 & Artemisia vulgaris & Mugwort & 2 & 2 & 82 & 88 & 105 & 10 & 190 \\
\hline FG3 & Argrostis capillaries & Common bent & 3 & 2 & 88 & 108 & 57 & 39 & 373 \\
\hline FG4 & Chamerion angustifolium & Rosebay willowherb & 1 & 2 & 19 & 25 & 6 & 3 & 53 \\
\hline FG5 & Agrostis tenuis & Slender rush & 3 & 10 & 731 & 456 & 317 & 256 & 558 \\
\hline FG6 & Dactylis glomerata & Cocksfoot & 2 & 10 & 77 & 212 & 28 & 27 & 180 \\
\hline FG7 & Urtica dioica & Stinging nettle & 2 & 7 & 61 & 59 & 16 & 15 & 124 \\
\hline FP1 & Galium aparine & Cleavers & 2 & UDL & 25 & 37 & 1 & 8 & 56 \\
\hline FP2 & Phalaris arundinacea & Reed canary grass & 3 & 2 & 14 & 34 & 3 & 14 & 111 \\
\hline FP3 & Heracleum sphondylium & Hogweed & 2 & UDL & 9 & 25 & 22 & 19 & 55 \\
\hline FP4 & Juncus inflexus & Hard rush & 5 & 8 & 43 & 192 & 8 & 19 & 88 \\
\hline FP5 & Impatiens glandulifera & Himalayan balsam & 4 & UDL & 38 & 42 & 15 & 12 & 119 \\
\hline MD1 & Plantago lanceolata & Ribowort plantain & 1 & 2 & 24 & 51 & 3 & 4 & 120 \\
\hline MD2 & Lolium multiflorum & Italian Rye grass & 4 & 1 & 22 & 207 & 3 & 13 & 215 \\
\hline MD3 & Juncus effusus & Soft rush & 24 & 4 & 27 & 89 & 9 & 31 & 116 \\
\hline MD4 & Chamerion angustifolium & Rosebay willowherb & 5 & 2 & 13 & 36 & 5 & 16 & 50 \\
\hline MD5 & Holcus lanatus & Yorkshire fog & 8 & 1 & 40 & 111 & 10 & 7 & 173 \\
\hline RS1 & Urtica dioica & Stinging nettle & 52 & 4 & 72 & 177 & 12 & 41 & 417 \\
\hline RS2 & Dactylis glomerata & Cocksfoot & 57 & 46 & 42 & 234 & 12 & 68 & 82 \\
\hline RS3 & Festuca pratensis & Meadow fescue & 32 & 3 & 23 & 225 & 5 & 48 & 83 \\
\hline RS4 & Glyceria maxima & Reed sweetgrass & 28 & 4 & 104 & 271 & 6 & 36 & 280 \\
\hline RS5 & Phleum pratense & Timothy grass & 29 & 3 & 47 & 584 & 16 & 26 & 161 \\
\hline RS6 & Lolium pratense & Ryegrass & 97 & 35 & 51 & 313 & 17 & 101 & 148 \\
\hline WH1 & Equisetum arvense & Field horsetail & 40 & 2 & 53 & 56 & 5 & 83 & 82 \\
\hline WH2 & Cynosurus cristatus & Crested dog's tail & 4 & 7 & 32 & 582 & 9 & 13 & 118 \\
\hline WH3 & Filipendula ulmaria & Meadowsweet & 4 & 4 & 54 & 187 & 7 & 19 & 141 \\
\hline WH4 & Bistorta officinalis & Bistort & 103 & 3 & 28 & 485 & 12 & 50 & 52 \\
\hline Median & & & 5 & 3 & 42 & 182 & 11 & 23 & 122 \\
\hline Min & & & 1 & UDL & 9 & 25 & 1 & 3 & 50 \\
\hline Max & & & 103 & 46 & 731 & 584 & 317 & 256 & 558 \\
\hline
\end{tabular}

UDL: under detection limit.

\subsubsection{Shoots}

The concentration of trace elements in the shoots of the investigated plant species is shown in Table 4. Like roots, it varied from plant species to plant species. The median concentration of various shoot-borne trace elements among all the investigated plant species are in the following decreasing order: $\mathrm{Zn}>\mathrm{Mn}>\mathrm{Cu}>\mathrm{Ni}>\mathrm{Pb}>\mathrm{As}>\mathrm{Cr}$, which is similar to that in the root portion. For As, the shoot-borne concentration ranged from UDL to $6.2 \mathrm{mg} / \mathrm{kg}$ with a median concentration 
of $0.7 \mathrm{mg} / \mathrm{kg}$. Phleum pratense had the highest shoot-borne As while the lowest shoot-borne As (UDL) was found in Dactylis glomerata. Other investigated plant species (Agrostis stolonifera, Argrostis capillaries, Chamerion angustifolium, Urtica dioica, Galium aparine, Phalaris arundinacea, Heracleum sphondylium, Impatiens glandulifera, Plantago lanceolate, Lolium multiflorum, Lolium pratense, Equisetum arvense, Cynosurus cristatus and Filipendula ulmaria) also had a very low As concentration in their shoots $(<1 \mathrm{mg} / \mathrm{kg}$ ). The shoot-borne $\mathrm{Cr}$ ranged from UDL to $0.8 \mathrm{mg} / \mathrm{kg}$ with a median concentration of $0.4 \mathrm{mg} / \mathrm{kg}$. Bistorta officinalis had the highest shoot-borne $\mathrm{Cr}(0.8 \mathrm{mg} / \mathrm{kg})$ while Chamerion angustifolium contained the least amount of shoot-borne Cr. The shoot-borne Cu ranged from 3.5 to $58.7 \mathrm{mg} / \mathrm{kg}$ with a median concentration of $8.5 \mathrm{mg} / \mathrm{kg}$. The shoot-borne Mn ranged from 9.1 to $540 \mathrm{mg} / \mathrm{kg}$ with a median concentration of $37.5 \mathrm{mg} / \mathrm{kg}$ for the investigated plant species. Bistorta officinalis contained the highest amount of shoot-borne Mn, followed by Phleum pratense while the lowest concentration of shoot-borne Mn was found in Urtica dioica. The shoot-borne Ni ranged from 0.8 to $52.8 \mathrm{mg} / \mathrm{kg}$. The mean concentration of $\mathrm{Ni}$ was $2.0 \mathrm{mg} / \mathrm{kg}$. Agrostis tenuis contained the highest amount of $\mathrm{Ni}$ in the shoot, followed by Artemisia vulgaris. The lowest shoot-borne Ni was found in Galium aparine that had only $0.8 \mathrm{mg} / \mathrm{kg}$. The concentration of $\mathrm{Pb}$ in the shoots ranged from 0.2 to $27.8 \mathrm{mg} / \mathrm{kg}$ with a median concentration of $1.79 \mathrm{mg} / \mathrm{kg}$. The highest concentration of shoot-borne $\mathrm{Pb}$ was found in Agrostis tenuis while Chamerion angustifolium had the lowest $\mathrm{Pb}$ concentration in the shoot among the investigated plant species. For shoot-borne $\mathrm{Zn}$, the concentration ranged from 14.5 to $189 \mathrm{mg} / \mathrm{kg}$ with a median value of $39.5 \mathrm{mg} / \mathrm{kg}$. Artemisia vulgaris contained the highest amount of $\mathrm{Zn}$ in the shoot, followed by Agrostis tenuis. Holcus lanatus had the lowest amount of $\mathrm{Zn}$ in the shoot among the investigated plant species.

Table 4. Concentration (mg element/ $\mathrm{kg}$ dry weight) of trace elements in the shoots of the investigated plant species.

\begin{tabular}{|c|c|c|c|c|c|c|c|c|c|}
\hline Location & Plant Species & Common Name & As & $\mathrm{Cr}$ & $\mathrm{Cu}$ & Mn & $\mathbf{N i}$ & $\mathbf{P b}$ & Zn \\
\hline FG1 & Agrostis stolonifera & Creeping bent & 1.0 & 0.6 & 10.3 & 37.5 & 23.9 & 3.4 & 53.8 \\
\hline FG2 & Artemisia vulgaris & Mugwort & 1.7 & 0.3 & 12.3 & 81.2 & 24.1 & 2.0 & 189 \\
\hline FG3 & Argrostis capillaries & Common bent & 0.3 & 0.2 & 10.5 & 33.3 & 13.5 & 2.3 & 67.9 \\
\hline FG4 & Chamerion angustifolium & Rosebay willowherb & 0.7 & UDL & 8.5 & 21.6 & 2.6 & 0.2 & 39.8 \\
\hline FG5 & Agrostis tenuis & Slender rush & 1.3 & 0.7 & 58.7 & 83.3 & 52.8 & 27.8 & 147 \\
\hline FG6 & Dactylis glomerata & Cocksfoot & 0.0 & 0.2 & 9.3 & 98.5 & 5.3 & 2.7 & 39.5 \\
\hline FG7 & Urtica dioica & Stinging nettle & 0.3 & 0.3 & 18.2 & 9.1 & 1.4 & 1.3 & 17.7 \\
\hline FP1 & Galium aparine & Cleavers & 0.4 & 0.1 & 4.4 & 14.8 & 0.8 & 1.1 & 25.7 \\
\hline FP2 & Phalaris arundinacea & Reed canary grass & 0.8 & 0.2 & 11.6 & 201 & 5.4 & 3.4 & 84.6 \\
\hline FP3 & Heracleum sphondylium & Hogweed & 0.3 & 0.4 & 6.7 & 17.1 & 1.6 & 2.3 & 56.8 \\
\hline FP4 & Juncus inflexus & Hard rush & 3.4 & 0.4 & 12.1 & 28.0 & 0.9 & 1.6 & 28.1 \\
\hline FP5 & Impatiens glandulifera & Himalayan balsam & 0.3 & 0.2 & 7.7 & 55.7 & 2.8 & 1.8 & 41.8 \\
\hline MD1 & Plantago lanceolata & Ribowort plantain & 0.4 & 0.3 & 4.8 & 10.6 & 1.1 & 1.2 & 19.7 \\
\hline MD2 & Lolium multiflorum & Italian Rye grass & 0.6 & 0.2 & 6.3 & 105 & 1.4 & 3.3 & 44.0 \\
\hline MD3 & Juncus effusus & Soft rush & 1.1 & 0.4 & 5.7 & 9.6 & 1.0 & 0.3 & 39.6 \\
\hline MD4 & Chamerion angustifolium & Rosebay willowherb & 0.7 & 0.4 & 7.2 & 27.9 & 1.0 & 1.4 & 32.4 \\
\hline MD5 & Holcus lanatus & Yorkshire fog & 0.6 & 0.7 & 4.2 & 12.4 & 1.0 & 1.2 & 14.5 \\
\hline RS1 & Urtica dioica & Stinging nettle & 0.3 & 0.2 & 10.4 & 28.9 & 1.4 & 2.0 & 22.3 \\
\hline RS2 & Dactylis glomerata & Cocksfoot & 1.5 & 0.3 & 5.7 & 33.3 & 1.9 & 2.5 & 21.4 \\
\hline RS3 & Festuca pratensis & Meadow fescue & 1.3 & 0.5 & 8.6 & 123 & 2.0 & 4.1 & 37.0 \\
\hline RS4 & Glyceria maxima & Reed sweetgrass & 2.6 & 0.4 & 7.1 & 92.1 & 1.1 & 1.3 & 25.5 \\
\hline RS5 & Phleum pratense & Timothy grass & 6.2 & 0.8 & 8.8 & 278 & 4.3 & 6.6 & 40.1 \\
\hline RS6 & Lolium pratense & Ryegrass & 0.2 & 0.3 & 4.9 & 124 & 2.6 & 1.7 & 26.3 \\
\hline WH1 & Equisetum arvense & Field horsetail & 0.7 & 0.6 & 10.7 & 43.7 & 1.3 & 3.6 & 50.9 \\
\hline WH2 & Cynosurus cristatus & Crested dog's tail & 0.4 & 0.6 & 5.2 & 178 & 3.7 & 1.6 & 35.3 \\
\hline WH3 & Filipendula ulmaria & Meadowsweet & UDL & 0.4 & 3.5 & 12.1 & 3.2 & 0.6 & 18.2 \\
\hline WH4 & Bistorta officinalis & Bistort & 1.0 & 0.8 & 8.8 & 540 & 3.5 & 0.6 & 63.4 \\
\hline Median & & & 0.7 & 0.4 & 8.5 & 37.5 & 2.0 & 1.8 & 39.5 \\
\hline Min & & & UDL & UDL & 3.5 & 9.1 & 0.8 & 0.2 & 14.5 \\
\hline Max & & & 6.2 & 0.8 & 58.7 & 540 & 52.8 & 27.8 & 189 \\
\hline
\end{tabular}

UDL: under detection limit. 


\section{Discussion}

\subsection{Trace Elements in the Investigated Soils}

From Table 2, it can be seen that the median concentration of $\mathrm{As}, \mathrm{Cu}, \mathrm{Pb}$ and $\mathrm{Zn}$ was about 30-, 4.5-, 9.6- and 1.8-fold higher than that in typical UK soils, respectively while Mn and Ni had the median concentration very similar to the respective UK-wide value [15]. The median concentrations of soil-borne $\mathrm{As}$ and $\mathrm{Pb}$ all well exceed the current UK screening levels for these two regulated soil elements [16]. There were a few spots with concurrent presence of $\mathrm{Cu}, \mathrm{Mn}, \mathrm{Ni}, \mathrm{Pb}$ and $\mathrm{Zn}$ at very high concentration (FG1, FG2, FG5 and RS3). Most of the soils had a concentration of Cr over $100 \mathrm{mg} / \mathrm{kg}$. There were seven spots where the concentration of As was greater than $500 \mathrm{mg} / \mathrm{kg}$ (Table 2). Pb concentration in the investigated soils were within the range previously reported by others [15,17-19] for British soils except in FG1, FG2, RS3 and WH1 soils where the observed Pb concentration was above the reported concentration range, indicating elevated level of $\mathrm{Pb}$ in these soils. The concentration of As in the investigated soils exceeded the upper limit of background As level (74.4 mg/kg) in British soils [17] except for the soils collected at FG1, FG4, FG5, FG6, FG7, FP4, FP5 and MD1 where the soil-borne As concentration was within the background As range. Cr levels observed in the investigated soils are within the range reported in literature for UK soils. Ni concentration in most of the investigated soils fell within the range reported for the British soils [15] and the world soils (0.2-450 mg/kg) [20] except for the soils collected from Locations FG1, FG2, FG5 and RS3 where elevated $\mathrm{Ni}$ level was present. $\mathrm{Cu}$ level in the investigated soils varied widely and in most investigated soils, $\mathrm{Cu}$ concentration was within the range reported for British soils $[15,17,21]$ except in FG1, FG2, FG5, FG6, FG7 and RS3 where elevated Cu levels were observed. The results indicated that Cu was among the most dominating heavy metals in FG soils. Zn concentration in most of the soils is in agreement with the range of soil-borne Zn reported for UK soils [15,18] except in FG1, FG2, FG5, FG7, FP2 and RS3 soils where elevated levels of Zn were observed. However, McGrath et al. [22] did report extremely high $\mathrm{Zn}$ concentration $(3648 \mathrm{mg} / \mathrm{kg})$ for some UK soils.

There was no clear relationship $\left(R^{2}<0.1\right)$ between the concentration of root-borne trace elements and $\mathrm{pH}$, suggesting that uptake of trace elements by plant roots was not controlled by soil $\mathrm{pH}$. Possibly, the low-molecular-weight organic acids released from the roots played a more important role in mobilizing the soil-borne trace elements in rhizosphere and thus making the trace elements available for the uptake by the plant roots.

\subsection{Bioaccumulation of Trace Elements}

Bioaccumulation factor, according to Zhao et al. [23], is defined as the capacity of a plant to accumulate a specific trace element with relation to its concentration in the soil. The ability of plants to take trace elements from soils can be quantified using bioaccumulation factor (BF). Bioaccumulation factor of trace elements in this study was calculated as a ratio of trace element concentration in plant root to that in the soil:

$$
\mathrm{BF}=\mathrm{C}_{\text {plant root }} / \mathrm{C}_{\text {soil }}
$$

where $\mathrm{C}_{\text {plant root }}$ and $\mathrm{C}_{\text {soil }}$ represent the concentration of a given trace element in plant root issue and in the corresponding soil sample, respectively.

The bioaccumulation factors of trace elements for the investigated plant species are presented in Table 5. It is evident that BF was highly variable among the different plant species growing in the soils with different physiochemical characteristics. This is consistent with work by Bose et al. [24]. The median value of BF for $\mathrm{Zn}$ was close to 1, indicating strong uptake of $\mathrm{Zn}$ by plant roots. Cu had a BF over 0.5 , followed by $\mathrm{Mn}$ and $\mathrm{Ni}$, which had a BF of more than 0.25 and nearly 0.15 , respectively. In comparison, the $\mathrm{BF}$ for $\mathrm{As}, \mathrm{Cr}$ and $\mathrm{Pb}$ in most of the plant species was below 0.1 , indicating that these trace elements have relatively low phyto-availability, which is consistent with the findings by Tiwari et al. [25]. 
Table 5. Bioaccumulation Factor of trace elements for the investigated plant species.

\begin{tabular}{|c|c|c|c|c|c|c|c|c|c|}
\hline Location & Plant Species & Common Name & As & $\mathrm{Cr}$ & $\mathrm{Cu}$ & Mn & $\mathbf{N i}$ & $\mathbf{P b}$ & $\mathrm{Zn}$ \\
\hline FG1 & Agrostis stolonifera & Creeping bent & 0.07 & 0.08 & 0.15 & 0.12 & 0.24 & 0.12 & 0.26 \\
\hline FG2 & Artemisia vulgaris & Mugwort & 0.02 & 0.01 & 0.02 & 0.03 & 0.12 & 0.01 & 0.19 \\
\hline FG3 & Argrostis capillaries & Common bent & 0.00 & 0.01 & 1.48 & 0.30 & 0.00 & 0.06 & 4.18 \\
\hline FG4 & Chamerion angustifolium & Rosebay willowherb & 0.11 & 0.05 & 0.10 & 0.06 & 0.11 & 0.02 & 0.29 \\
\hline FG5 & Agrostis tenuis & Slender rush & 0.09 & 0.08 & 0.59 & 0.13 & 0.30 & 0.29 & 0.30 \\
\hline FG6 & Dactylis glomerata & Cocksfoot & 0.05 & 0.10 & 0.19 & 0.28 & 0.19 & 0.08 & 0.83 \\
\hline FG7 & Urtica dioica & Stinging nettle & 0.04 & 0.05 & 0.10 & 0.06 & 0.12 & 0.04 & 0.22 \\
\hline FP1 & Galium aparine & Cleavers & 0.01 & 0.00 & 0.32 & 0.07 & 0.02 & 0.02 & 0.39 \\
\hline FP2 & Phalaris arundinacea & Reed canary grass & 0.02 & 0.02 & 0.08 & 0.05 & 0.04 & 0.03 & 0.25 \\
\hline FP3 & Heracleum sphondylium & Hogweed & 0.00 & 0.00 & 0.07 & 0.05 & 1.31 & 0.02 & 0.23 \\
\hline FP4 & Juncus inflexus & Hard rush & 0.10 & 0.07 & 0.67 & 0.45 & 0.15 & 0.14 & 0.69 \\
\hline FP5 & Impatiens glandulifera & Himalayan balsam & 0.08 & 0.00 & 0.64 & 0.10 & 0.27 & 0.09 & 1.00 \\
\hline MD1 & Plantago lanceolata & Ribowort plantain & 0.04 & 0.02 & 0.75 & 0.09 & 0.23 & 0.09 & 1.67 \\
\hline MD2 & Lolium multiflorum & Italian Rye grass & 0.00 & 0.01 & 0.58 & 4.22 & 0.00 & 0.02 & 7.69 \\
\hline MD3 & Juncus effusus & Soft rush & 0.09 & 0.03 & 0.77 & 0.26 & 1.51 & 0.16 & 1.63 \\
\hline MD4 & Chamerion angustifolium & Rosebay willowherb & 0.01 & 0.01 & 0.16 & 0.12 & 0.00 & 0.02 & 0.56 \\
\hline MD5 & Holcus lanatus & Yorkshire fog & 0.04 & 0.01 & 0.71 & 0.26 & 0.89 & 0.03 & 1.43 \\
\hline RS1 & Urtica dioica & Stinging nettle & 0.15 & 0.02 & 0.93 & 0.50 & 0.51 & 0.12 & 2.39 \\
\hline RS2 & Dactylis glomerata & Cocksfoot & 0.13 & 0.27 & 0.81 & 0.65 & 0.54 & 0.21 & 0.86 \\
\hline RS3 & Festuca pratensis & Meadow fescue & 0.36 & 0.02 & 0.01 & 0.12 & 0.01 & 0.04 & 0.06 \\
\hline RS4 & Glyceria maxima & Reed sweetgrass & 0.09 & 0.03 & 1.39 & 0.52 & 0.69 & 0.11 & 2.36 \\
\hline RS5 & Phleum pratense & Timothy grass & 0.03 & 0.01 & 0.53 & 0.26 & 0.00 & 0.04 & 1.76 \\
\hline RS6 & Lolium pratense & Ryegrass & 0.14 & 0.16 & 0.58 & 1.23 & 0.00 & 0.18 & 1.36 \\
\hline WH1 & Equisetum arvense & Field horsetail & 0.04 & 0.01 & 0.86 & 0.15 & 0.00 & 0.06 & 0.92 \\
\hline WH2 & Cynosurus cristatus & Crested dog's tail & 0.04 & 0.06 & 0.24 & 1.86 & 0.96 & 0.09 & 1.23 \\
\hline WH3 & Filipendula ulmaria & Meadowsweet & 0.01 & 0.03 & 1.07 & 0.40 & 0.00 & 0.08 & 1.32 \\
\hline WH4 & Bistorta officinalis & Bistort & 0.82 & 0.03 & 0.52 & 1.23 & 0.72 & 0.34 & 0.52 \\
\hline Median & & & 0.04 & 0.02 & 0.58 & 0.26 & 0.15 & 0.08 & 0.86 \\
\hline Min & & & 0.00 & 0.00 & 0.01 & 0.03 & 0.00 & 0.01 & 0.06 \\
\hline Max & & & 0.82 & 0.27 & 1.48 & 4.22 & 1.51 & 0.34 & 7.69 \\
\hline
\end{tabular}

Some plant species showed unusual capacity to take certain trace elements from the soils. For As, Bistorta officinalis had much higher BF, as compared to other plant species. Three plant species had BF $>1$ for Cu: Argrostis capillaries, Glyceria maxima, Filipendula ulmaria. There were four plant species with $\mathrm{BF}>1$ for Mn, including Lolium pratense, Cynosurus cristatus, Bistorta officinalis and Lolium multiflorum with the Lolium multiflorum having a BF $>4$. For Ni, Heracleum sphondylium and Juncus effuses had the $\mathrm{BF}>1$. It is interesting to note that nearly half of the investigated plant species had a BF greater than 1 for Zn with Lolium multiflorum having a BF as high as 7.69. It has been previously reported that Lolium multiflorum could tolerate high concentrations of heavy metals in mine soils and has the capacity to phytoextract a range of heavy metals from soils [26]. In addition, Dactylis glomerate and Bistorta officinalis had the capacity to phytoextract a wide range of trace elements.

\subsection{Root-Shoot Translocation}

The translocation factor (TF) is used here to evaluate the translocation of trace elements from plant root to shoot [27]. The TF is calculated as a ratio of trace element concentration in plant shoot to that in plant root:

$$
\mathrm{TF}=\mathrm{C}_{\text {plant shoot }} / \mathrm{C}_{\text {plant root }}
$$

The TFs for the 27 investigated plant samples are given in Table 6. In general, the TF among the investigated plant species was extremely variable. The median value of TF for various trace elements was in the following decreasing order: $\mathrm{Mn}>\mathrm{Zn}>\mathrm{Ni}>\mathrm{Cu}>\mathrm{As}>\mathrm{Cr}>\mathrm{Pb}$. Manganese, zinc and nickel are readily transported via xylem to the shoot [28]. The high rate of root-shoot translocation for $\mathrm{Mn}$ $\mathrm{Zn}, \mathrm{Ni}$ and $\mathrm{Cu}$ was also noted by other workers [29-33]. 
Table 6. Translocation factor of trace elements for the investigated plant species.

\begin{tabular}{|c|c|c|c|c|c|c|c|c|c|}
\hline Location & Plant Species & Common Name & As & $\mathrm{Cr}$ & $\mathrm{Cu}$ & Mn & $\mathbf{N i}$ & $\mathrm{Pb}$ & $\mathrm{Zn}$ \\
\hline FG1 & Agrostis stolonifera & Creeping bent & 0.19 & 0.01 & 0.02 & 0.08 & 0.13 & 0.02 & 0.16 \\
\hline FG2 & Artemisia vulgaris & Mugwort & 0.92 & 0.15 & 0.15 & 0.92 & 0.22 & 0.20 & 0.99 \\
\hline FG3 & Argrostis capillaries & Common bent & 0.08 & 0.09 & 0.12 & 0.31 & 0.23 & 0.06 & 0.18 \\
\hline FG4 & Chamerion angustifolium & Rosebay willowherb & 0.48 & 0.02 & 0.44 & 0.85 & 0.41 & 0.05 & 0.74 \\
\hline FG5 & Agrostis tenuis & Slender rush & 0.39 & 0.07 & 0.08 & 0.18 & 0.16 & 0.11 & 0.26 \\
\hline FG6 & Dactylis glomerata & Cocksfoot & 0.00 & 0.02 & 0.12 & 0.46 & 0.19 & 0.10 & 0.22 \\
\hline FG7 & Urtica dioica & Stinging nettle & 0.12 & 0.05 & 0.30 & 0.16 & 0.08 & 0.09 & 0.14 \\
\hline FP1 & Galium aparine & Cleavers & 0.16 & 0.00 & 0.17 & 0.39 & 0.59 & 0.13 & 0.45 \\
\hline FP2 & Phalaris arundinacea & Reed canary grass & 0.27 & 0.10 & 0.83 & 5.42 & 1.76 & 0.25 & 0.76 \\
\hline FP3 & Heracleum sphondylium & Hogweed & 0.16 & 1.94 & 0.75 & 0.69 & 0.07 & 0.12 & 1.03 \\
\hline FP4 & Juncus inflexus & Hard rush & 0.63 & 0.05 & 0.28 & 0.15 & 0.12 & 0.08 & 0.32 \\
\hline FP5 & Impatiens glandulifera & Himalayan balsam & 0.07 & 0.54 & 0.20 & 1.31 & 0.19 & 0.15 & 0.34 \\
\hline MD1 & Plantago lanceolata & Ribowort plantain & 0.28 & 0.15 & 0.20 & 0.21 & 0.43 & 0.29 & 0.16 \\
\hline MD2 & Lolium multiflorum & Italian Rye grass & 0.56 & 0.13 & 0.28 & 0.51 & 0.50 & 0.25 & 0.20 \\
\hline MD3 & Juncus effusus & Soft rush & 0.04 & 0.09 & 0.21 & 0.11 & 0.11 & 0.01 & 0.34 \\
\hline MD4 & Chamerion angustifolium & Rosebay willowherb & 0.14 & 0.17 & 0.58 & 0.78 & 0.18 & 0.09 & 0.65 \\
\hline MD5 & Holcus lanatus & Yorkshire fog & 0.07 & 0.94 & 0.10 & 0.11 & 0.10 & 0.16 & 0.08 \\
\hline RS1 & Urtica dioica & Stinging nettle & 0.01 & 0.06 & 0.15 & 0.16 & 0.12 & 0.05 & 0.05 \\
\hline RS2 & Dactylis glomerata & Cocksfoot & 0.03 & 0.01 & 0.13 & 0.14 & 0.16 & 0.04 & 0.26 \\
\hline RS3 & Festuca pratensis & Meadow fescue & 0.04 & 0.12 & 0.38 & 0.55 & 0.44 & 0.09 & 0.44 \\
\hline RS4 & Glyceria maxima & Reed sweetgrass & 0.10 & 0.09 & 0.07 & 0.34 & 0.18 & 0.04 & 0.09 \\
\hline RS5 & Phleum pratense & Timothy grass & 0.21 & 0.28 & 0.19 & 0.48 & 0.27 & 0.25 & 0.25 \\
\hline RS6 & Lolium pratense & Ryegrass & 0.00 & 0.01 & 0.10 & 0.40 & 0.15 & 0.02 & 0.18 \\
\hline WH1 & Equisetum arvense & Field horsetail & 0.02 & 0.26 & 0.20 & 0.78 & 0.26 & 0.04 & 0.06 \\
\hline WH2 & Cynosurus cristatus & Crested dog's tail & 0.09 & 0.08 & 0.16 & 0.31 & 0.40 & 0.12 & 0.30 \\
\hline WH3 & Filipendula ulmaria & Meadowsweet & 0.01 & 0.11 & 0.06 & 0.06 & 0.44 & 0.03 & 0.13 \\
\hline WH4 & Bistorta officinalis & Bistort & 0.01 & 0.25 & 0.31 & 1.11 & 0.29 & 0.01 & 1.22 \\
\hline Median & & & 0.10 & 0.09 & 0.19 & 0.39 & 0.19 & 0.09 & 0.26 \\
\hline Min & & & 0.00 & 0.00 & 0.02 & 0.06 & 0.07 & 0.01 & 0.05 \\
\hline Max & & & 0.92 & 1.94 & 0.83 & 5.42 & 1.76 & 0.29 & 1.22 \\
\hline
\end{tabular}

Several plant species had TFs near to or greater than 1 at least for one trace element and therefore can be regarded as hyperaccumulating plants [34]. These include Artemisia vulgaris for As, Mn and Zn, Phalaris arundinacea for $\mathrm{Mn}$ and $\mathrm{Ni}$, Heracleum sphondylium for $\mathrm{Cr}$ and $\mathrm{Zn}$, and Bistorta officinalis for $\mathrm{Mn}$ and Zn. It is interesting to note that Phalaris arundinacea has a TF as high as 5.42 for Mn, suggesting that it could be a high-performing Mn hyperaccumulator. This finding is in contrast with Polechońska and Klink [35] who found that the root-shoot translocation of heavy metals was limited.

\subsection{Environmental Implications}

Information on trace elements in wild plants is rare. By comparison with other available reports, it is evident that the levels of shoot-borne trace elements in the investigated study area tended to be higher than those reported by Misra and Mani [36] and MacLean et al. [37] except for As and Cr (Table 7). In particular, several plant species are capable of accumulating multiple trace elements and have a very high level of combined trace elements in the shoot portion (sum of all the investigated trace elements). These include Artemisia vulgaris, Agrostis tenuis, Phalaris arundinacea, Phleum pratense and Bistorta officinalis (Figure 2). 
Table 7. A comparison of shoot-borne trace elements (mg element/kg dry weight) between this study and other reports.

\begin{tabular}{cccc}
\hline Element & Misra and Mani [36] & MacLean et al. [37] & This Study \\
\hline $\mathrm{As}$ & $0.02-7$ & - & $0-6.18$ \\
$\mathrm{Cr}$ & $0.2-1$ & 1.22 & $0.04-0.78$ \\
$\mathrm{Cu}$ & 4.15 & 12.3 & $3.46-58.7$ \\
$\mathrm{Mn}$ & $15-100$ & - & $9.14-540$ \\
$\mathrm{Ni}$ & 1 & 4.08 & $0.75-52.8$ \\
$\mathrm{~Pb}$ & $1-13$ & 1.54 & $0.16-27.8$ \\
$\mathrm{Zn}$ & $8-100$ & 28.4 & $14.5-189$ \\
\hline
\end{tabular}

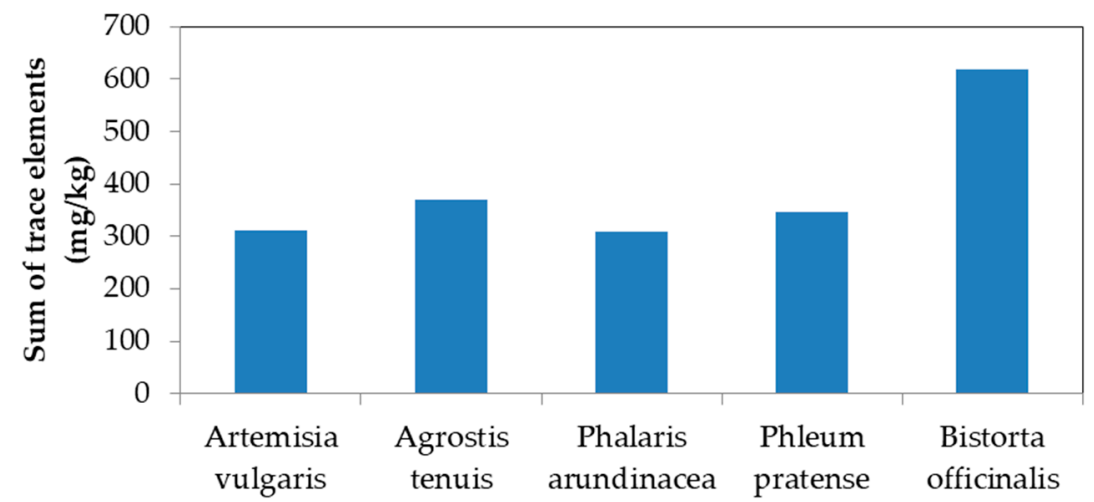

Figure 2. Sum of various trace elements $(\mathrm{mmol} / \mathrm{kg})$ in the shoot portion for the five top plant species.

Heavy metal uptake by vegetable plants has been a topic receiving great attention due to the human health risk associated with consumption of contaminated vegetable products [38-40]. There has been a movement to develop urban agriculture by using available lands near residential areas such as the investigated area [41]. The marked accumulation of trace elements in some investigated plant species suggests that it is possible that certain types of vegetable plants could take substantial amounts of trace elements from the soils if the site is used as urban farms for agricultural production. Therefore, caution must be taken to evaluate the human health risk associated with any potential urban agriculture development.

Although the investigated herbaceous plants do not have direct impacts on human health due to their non-human-consumable nature, the plant tissue-borne trace elements could affect the ecosystem functioning in the affected areas. The generally high concentration of trace elements in the root could affect soil animals and microorganisms that feed on the root-derived organic matter [42-45]. If the site is used for cattle grazing, the shoot-borne trace elements could potentially affect the health of the grazing animals and accumulate in the animal tissues, which in turn affect human health through the food chain.

\section{Conclusions}

The investigated soils were contaminated by multiple trace elements with the median concentration being in the following decreasing order: $\mathrm{Mn}>\mathrm{Pb}>\mathrm{As}>\mathrm{Cr}>\mathrm{Zn}>\mathrm{Cu}>\mathrm{Ni}$. The median concentration of trace elements in the roots of the investigated plant species was in the following decreasing order: $\mathrm{Mn}>\mathrm{Zn}>\mathrm{Cu}>\mathrm{Pb}>\mathrm{Ni}>\mathrm{As}>\mathrm{Cr}$ while the median concentration of trace elements in the shoots of the investigated plant species showed the following decreasing order: $\mathrm{Zn}>\mathrm{Mn}>$ $\mathrm{Cu}>\mathrm{Ni}>\mathrm{Pb}>\mathrm{As}>\mathrm{Cr}$. The bioaccumulation factor was highly variable among the different plant species. Uptake of $\mathrm{Zn}$ by plant roots was strong with a median BF of 0.856 . $\mathrm{Cu}$ and $\mathrm{Mn}$ had a BF over 0.5 and 0.25 , respectively. These were followed by Ni with a BF nearly 0.15 . In comparison, As, $\mathrm{Cr}$ and $\mathrm{Pb}$ tended to have relatively low phyto-availability with the median BFs being $<0.1$ for most of the plant species. The translocation factor among the investigated plant species was considerably 
variable. In terms of median value, TF for various trace elements was in the following decreasing order: $\mathrm{Mn}>\mathrm{Zn}>\mathrm{Ni}>\mathrm{Cu}>\mathrm{As}>\mathrm{Cr}>\mathrm{Pb}$. Potential hyperaccumulating plants identified from this study included Artemisia vulgaris for As, Mn and $\mathrm{Zn}$, Phalaris arundinacea for $\mathrm{Mn}$ and $\mathrm{Ni}$, Heracleum sphondylium for $\mathrm{Cr}$ and $\mathrm{Zn}$, and Bistorta officinalis for $\mathrm{Mn}$ and $\mathrm{Zn}$. The marked accumulation of trace elements in the plant tissue suggests that the site may not be suitable for urban agricultural production. The plant tissue-borne trace elements could affect the ecosystem functioning in the affected areas. The findings obtained from this study provide a basis for further work to obtain insights into plant uptake of the trace elements contained in the investigated soils through long-term field monitoring and greenhouse experiments.

Author Contributions: Conceptualization, O.E.N. and C.L.; Methodology, O.E.N. and J.Q.; Formal Analysis, C.L. and O.E.N.; Investigation, O.E.N. and J.Q.; Writing-Original Draft Preparation, O.E.N., J.Q. and C.L.; Writing-Review \& Editing, C.L.; Supervision, C.L.

Funding: This research received no external funding.

Conflicts of Interest: The authors declare no conflict of interest.

\section{References}

1. Ali, H.; Khan, E.; Sajad, M.A. Phytoremediation of heavy metals-concepts and applications. Chemosphere 2013, 91, 869-881. [CrossRef] [PubMed]

2. Brun, L.A.; Maillet, J.; Hinsinger, P.; Pepin, M. Evaluation of copper availability to plants in copper-contaminated vineyard soils. Environ. Pollut. 2001, 111, 293-302. [CrossRef]

3. Ginocchio, R.; Rodríguez, P.H.; Badilla-Ohlbaum, R.; Allen, H.E.; Lagos, G.E. Effect of soil copper content and $\mathrm{pH}$ on copper uptake of selected vegetables grown under controlled conditions. Environ. Toxicol. Chem. 2002, 21, 1736-1744. [CrossRef] [PubMed]

4. Yoon, J.; Cao, X.; Zhou, Q.; Ma, L.Q. Accumulation of Pb, Cu, and $\mathrm{Zn}$ in Native Plants Growing on a Contaminated Florida Site. Sci. Total Environ. 2006, 368, 456-464. [CrossRef] [PubMed]

5. Elless, M.P.; Blaylock, M.J.; Huang, J.W.; Gussman, C.D. Plants as a natural source of concentrated mineral nutritional supplements. Food Chem. 2000, 71, 181-188. [CrossRef]

6. Ye, X.; Li, H.; Ma, Y.; Wu, L.; Sun, B. The bioaccumulation of $\mathrm{Cd}$ in rice grains in paddy soils as affected and predicted by soil properties. J. Soils Sediment. 2014, 14, 1407-1416. [CrossRef]

7. Adams, M.L.; Zhao, F.J.; McGrath, S.P.; Nicholson, F.A.; Chambers, B.J. Predicting cadmium concentrations in wheat and barley grain using soil properties. J. Environ. Qual. 2004, 33, 532-541. [CrossRef]

8. Cao, F.; Wang, R.; Cheng, W.; Zeng, F.; Ahmed, I.M.; Hu, X.; Wu, F. Genotypic and environmental variation in cadmium, chromium, lead and copper in rice and approaches for reducing the accumulation. Sci. Total Environ. 2014, 496, 275-281. [CrossRef]

9. Warne, M.S.J.; Heemsbergen, D.; Stevens, D.; McLaughlin, M.; Cozens, G.; Whatmuff, M.; Pritchard, D. Modeling the toxicity of copper and zinc salts to wheat in 14 soils. Environ. Toxicol. Chem. 2008, 27, 786-792. [CrossRef]

10. Liu, W.X.; Shen, L.F.; Liu, J.W.; Wang, Y.W.; Li, S.R. Uptake of toxic heavy metals by rice (Oryza sativa L.) cultivated in the agricultural soil near Zhengzhou City, People's Republic of China. Bull. Environ. Contam. Toxicol. 2007, 79, 209-213. [CrossRef]

11. Nguyen, T.H.; Sakakibara, M.; Sano, S.; Hori, R.S.; Sera, K. The Potentialof Eleocharis acicularis for Phytoremediation: Case Study at an Abandoned Mine Site, Clean. Soil Air Water 2009, 37, 203-208.

12. Ranjeev, K.S.; Ram, N.; Vishal, C. Accumulation of Metals in NaturallyGrown Weeds (Aquatic Macrophytes) Grown on an Industrial Effluent Channel, Clean. Soil Air Water 2007, 35, 261-265.

13. Groundwork Oldham and Rochdale. Moston Brook Feasibility Study; Manchester City Council: Manchester, UK, 2008.

14. Bressy, F.C.; Brito, G.B.; Barbosa, I.S.; Teixeira, L.S.; Korn, M.G.A. Determination of trace element concentrations in tomato samples at different stages of maturation by ICP OES and ICP-MS following microwave-assisted digestion. Microchem. J. 2013, 109, 145-149. [CrossRef] 
15. Ross, S.M.; Wood, M.D.; Copplestone, D.; Warriner, M.; Crook, P. Environmental Concentrations of Heavy Metals in UK Soil and Herbage; UK Soil and Herbage Pollutant Survey (UKSHS) Report; Environment Agency: Bristo, UK, 2007.

16. DEFRA. Development of Category 4 Screening Levels for Assessment of Land Affected by Contamination; Final Project Report (Revision 2); Department for Environment, Food and Rural Affairs: London, UK, 2014.

17. Johnson, C.C.; Ander, E.L.; Cave, M.R.; Palumbo-Roe, B. Normal Background Concentrations (NBCs) of Contaminants in English Soils: Final Project Report. 2012. Available online: https:/ / www.bgs.ac.uk/gbase/ NBCDefraProject.html (accessed on 1 December 2018).

18. Alloway, B.J. Heavy Metals in Soils; Chapman \& Hall: London, UK, 1995.

19. McGrath, S.P. Range of Metal Concentrations in Topsoils of England and Wales in Relation to Soil Protection Guidelines (No. CONF-860626-); Rothamsted Experimental Station: Harpenden, UK, 1986.

20. Kabata-Pendias, A. Trace Elements in Soils and Plants, 3rd ed.; CRC Press: Boca Raton, FL, USA, 2000.

21. Archer, F.C.; Hodgson, I.H. Total and extractable trace element contents of soils in England and Wales. J. Soil Sci. 1987, 38, 421-431. [CrossRef]

22. McGrath, S.P.; Loveland, P.J. The Soil Geochemical Atlas of England and Wales; Blackie Academic \& Professional: Glasgow, UK, 1992.

23. Zhao, F.J.; Lombi, E.; McGrath, S.P. Assessing the potential for zinc and cadmium phytoremediation with the hyperaccumulator Thlaspi caerulescens. Plant Soil 2003, 249, 37-43. [CrossRef]

24. Bose, S.; Vedamati, J.; Rai, V.; Ramanathan, A.L. Metal uptake and transport by Tyaha angustata L. grown on metal contaminated waste amended soil: An implication of phytoremediation. Geoderma 2008, 145, 136-142. [CrossRef]

25. Tiwari, K.K.; Singh, N.K.; Patel, M.P.; Tiwari, M.R.; Rai, U.N. Metal contamination of soil and translocation in vegetables growing under industrial wastewater irrigated agricultural field of Vadodara, Gujarat, India. Ecotoxicol. Environ. Saf. 2011, 74, 1670-1677. [CrossRef]

26. Mugica-Alvarez, V.; Cortés-Jiménez, V.; Vaca-Mier, M.; Domínguez-Soria, V. Phytoremediation of Mine Tailings Using Lolium Multiflorum. Int. J. Environ. Sci. Dev. 2015, 6, 246-251. [CrossRef]

27. Galal, T.M.; Shehata, H.S. Bioaccumulation and translocation of heavy metals by Plantago major L. grown in contaminated soils under the effect of traffic pollution. Ecol. Indic. 2015, 48, 244-251. [CrossRef]

28. Page, V.; Feller, U. Heavy Metals in crop plants: Transport and redistribution processes on the whole plant level. Agronomy 2015, 5, 447-463. [CrossRef]

29. Ximénez-Embún, P.; Rodríguez-Sanz, B.; Madrid-Albarrán, Y.; Cámara, C. Uptake of heavy metals by lupin plants in artificially contaminated sand: Preliminary results. Int. J. Environ. Anal. Chem. 2002, 82, 805-813. [CrossRef]

30. Page, V.; Feller, U. Selective transport of zinc, manganese, nickel, cobalt and cadmium in the root system and transfer to the leaves in young wheat plants. Ann. Bot. 2005, 96, 425-434. [CrossRef] [PubMed]

31. Chandra, R.; Bharagava, R.N.; Yadav, S.; Mohan, D. Accumulation and distribution of toxic metals in wheat (Triticum aestivum L.) and Indian mustard (Brassica campestris L.) irrigated with distillery and tannery effluents. J. Hazard. Mater. 2009, 162, 1514-1521. [CrossRef] [PubMed]

32. Han, D.F.; Luo, D.; Chen, Y.H.; Wang, G. Transfer of Cd, Pb, and $\mathrm{Zn}$ to water spinach from a polluted soil amended with lime and organic materials. J. Soils Sediment. 2013, 13, 1360-1368. [CrossRef]

33. Kamari, A.; Yusoff, M.; Najiah, S.; Putra, W.P.; Ishak, C.F.; Hashim, N.; Mohamed, A.; Phillip, E. Metal uptake in water spinach grown on contaminated soil amended with chicken manure and coconut tree sawdust. Environ. Eng. Manag. J. 2014, 13, 2219-2228. [CrossRef]

34. Tangahu, B.V.; Abdullah, S.R.S.; Basri, H.; Idris, M.; Anuar, N.; Mukhlisin, M. A review on heavy metals (As, $\mathrm{Pb}$, and $\mathrm{Hg}$ ) uptake by plants through phytoremediation. Int. J. Chem. Eng. 2011, 2011, 939161. [CrossRef]

35. Polechońska, L.; Klink, A. Trace metal bioindication and phytoremediation potentialities of Phalaris arundinacea L. (reed canary grass). J. Geochem. Explor. 2014, 146, 27-33. [CrossRef]

36. Misra, S.G.; Mani, D. Soil Pollution; Ashish Publishing House: Punjabi Bagh, India, 1991.

37. MacLean, K.S.; Robinson, A.R.; MacConnell, H.H. The effect of sewage-sludge on the heavy metal content of soils and plant tissue. Commun. Soil Sci. Plan. 1987, 18, 1303-1316. [CrossRef]

38. Stalikas, C.D.; Mantalovas, A.C.; Pilidis, G.A. Multielement concentrations in vegetable species grown in two typical agricultural areas of Greece. Sci. Total Environ. 1997, 206, 17-24. [CrossRef] 
39. Gupta, N.; Khan, D.K.; Santra, S.C. An assessment of heavy metal contamination in vegetables grown in wastewater-irrigated areas of Titagarh, West Bengal, India. Bull. Environ. Contam. Toxicol. 2008, 80, 115-118. [CrossRef]

40. Pan, X.D.; Wu, P.G.; Jiang, X.G. Levels and potential health risk of heavy metals in marketed vegetables in Zhejiang, China. Sci. Rep. 2016, 6, 20317. [CrossRef] [PubMed]

41. Adams, D.; Scott, A.J.; Hardman, M. Guerrilla warfare in the planning system: Revolution or convergence in sustainable planning discourse? Geogr. Ann. 2014, 95, 375-387. [CrossRef]

42. Wong, M.H. Ecological restoration of mine degraded soils, with emphasis on metal contaminated soils. Chemosphere 2003, 50, 775-780. [CrossRef]

43. Khan, A.G. Role of soil microbes in the rhizospheres of plants growing on trace metal contaminated soils in phytoremediation. J. Trace Elem. Med. Biol. 2005, 18, 355-364. [CrossRef] [PubMed]

44. Pacwa-Płociniczak, M.; Płociniczak, T.; Yu, D. Effect of silene vulgaris and heavy metal pollution on soil microbial diversity in long-term contaminated soil. Water Air Soil Pollut. 2018, 229, 13. [CrossRef] [PubMed]

45. Jiang, R.; Wang, M.; Chen, W.; Li, X. Ecological risk evaluation of combined pollution of herbicide siduron and heavy metals in soils. Sci. Total Environ. 2018, 626, 1047-1056. [CrossRef] [PubMed]

(C) 2019 by the authors. Licensee MDPI, Basel, Switzerland. This article is an open access article distributed under the terms and conditions of the Creative Commons Attribution (CC BY) license (http:/ / creativecommons.org/licenses/by/4.0/). 